\title{
APROPIEREA COPILULUI DE VALORILE RELIGIOASE. ROLUL DISCIPLINEI OPŢIONALE ELEMENTE DE PRACTICĂ RELIGIOASĂ
}

\author{
Irina Maria Matei*
}

\begin{abstract}
The child approaching of the religious values. The role of the optional subject "Elements of the Religious Practice. The religion lesson in school aim to near human to God and helps to put into practice christian teachings. However, one hour per week is not enough throughgoing study and skills, but the optional is a way to remedy the situation. The optional is a precious instrument that opens new oportunities in developing pupils both at home and abroad. Also in this paper we'll describe the process of the developing of the religious skills and the liturgical practice. Therefore, we consider welcome the proposing of an optional for the 4th grade and observing its impact. We based our work by the adapted use of the learning content to the children particularities will produce positive changes in their affective and volitional behaviour and cognitive process. Our results were obtained using the followings methods: direct observation, investigation, school documents and analysing the pupils activity products and tests. With these means and methods, we could see the progress registered by the pupils in three fields: cognitive, affective and volitive.
\end{abstract}

Keywords: optional, religion, liturgical practice, spiritual life

\section{Introducere}

Deoarece vârsta copilăriei reprezintă terenul curat, şi cel mai bun pentru a semăna Cuvântul lui Dumnezeu, este vârsta la care orice rugăciune mică este trăită şi prinde viaţă pe buzele curate ale

\footnotetext{
Teacher at "Dosa Daniel" Secondary School, Valea Izvoarelor, Mureş County, Romania.
} 
micuţilor creştini. Ce poate fi mai util şi mai frumos transmis către sufletul copilului decât imaginile supreme ale binelui, cinstei şi purităţii reprezentate de Mântuitorul nostru Iisus Hristos, Care le porunceşte creştinilor să dea copiilor educaţie spirituală din cea mai fragedă vârstă.

Îndemnul Mântuitorului ... Lăsaţi copiii să vină la Mine şi nu-i opriţi, căci a unora ca aceştia este Împărăţia lui Dumnezeu (Mc. 10, 14) răsună peste veacuri chemând omul la împlinirea voii dumnezeieşti, după cum sublinia Sfântul Grigorie de Nyssa Voia lui Dumnezeu cea desăvârşită este de a-şi întipări cineva în suflet chipul vieţuirii binecredincioase ${ }^{1}$. Ora de religie ajută în formarea personalităţii umane la nivel cognitiv, afectiv, volitiv şi atitudinal, prin potenţialul formativ-educativ al valorilor creştine propuse ${ }^{2}$.

Prezenţa opţionalului la religie este cu atât mai oportună cu cât timpul alocat studiului religiei, o oră pe săptămână, nu permite anumite aprofundări ale conţinutului învăţării, fixarea unor noţiuni şi formarea deprinderilor de comportament moral-religios. Opţionalul reprezintă întreaga experienţă de învătare-formare propusă de şcoală prin activităţi şcolare şi extraşcolare. Această experienţă se realizează prin ansamblul funcţional al componentelor şi tipurilor curriculare proiectate şi aplicate în interdependenţă $\breve{a}^{3}$. Dată fiind varietatea modelelor de proiectare, curriculumul la decizia şcolii impune elaborarea de documente şcolare, dar are marele avantaj al flexibilităţii în abordare. Muşata Bocoş susţine că principala provocare a curriculum-ului o reprezintă transpunerea, traducerea

\footnotetext{
${ }^{1}$ Sfântul Grigorie de Nyssa, Despre rânduiala cea după Dumnezeu (a vieţii) şi despre nevoinţa cea adevărată, în „Scrieri”, partea întâi, trad. de D. Stăniloae şi I. Buga, în col. „Părinţi şi Scriitori Bisericeşti”, vol. 29, Bucureşti, Edit. Institutului Biblic şi de Misiune al Bisericii Ortodoxe Române, 1982, p. 459.

2 Gheorghe Holbea, Dorin Opriş, Monica Opriş, and George Jambore, Apostolat educaţional, ora de religie - cunoaştere şi devenire spirituală, Bucureşti, Edit. Basilica a Patriarhiei Române, 2010, p. 38.

${ }^{3}$ Contantin Cucoş (coord.), Psihopedagogie pentru examenele de definitivare şi grade didactice, Iaşi, Edit. Polirom, 1998, p. 105.
} 
temelor de studiat în experiențe de învățare şi formare relevante ${ }^{4}$. Ca parte integrantă a opţionalului de religie, formarea deprinderilor religioase prin practica liturgică vizează scopul formativ al educaţiei religioase, aceasta fiind o coordonată importantă în procesul de formare a omului, care se cere exersată, pentru a putea fi interiorizată, întrucât crearea condiţiilor pentru transferul achiziţ̧iilor specifice domeniului din planul informativ, în cel practic constituie baza educaţiei religioase. Astfel, exersarea în şcoală a deprinderilor religioase îl ajută pe copil să participe la cultul divin într-un mod conştient, iar după Dorin Opriş se poate identifica o relaţie intre jertfa euharistică și jertfa celui care participă activ la slujbele religioase, cântând $d^{5}$. Pe măsură ce creşte, copilul, ajunge să înţeleagă tot mai mult mesajul sfintelor slujbe, etapă în care rolul părinţilor este semnificativ, în special pentru susţinerea trăirii religioase, elevii reuşind să observe mai târziu arta creştină, în special în locaşul de cult, toate acestea atingându-şi apogeul în manifestarea iubirii pentru aproapele.

\section{Perspective asupra opţionalului în diverse sisteme de învăţământ}

În ţări precum Suedia abordarea opţionalelor presupune implementarea reformelor şcolare menite să îmbunătăţească atât rezultatele cât şi să ridice statutul profesiei didactice. Opţionalele vizate în această ţară au aceeaşi durată, (un an), ca şi în ţara noastră, programa fiind adaptată la nevoile şi cerinţele elevilor cu scopul de a oferi un fundament bun pentru a continua studiile, indiferent de nivel. De exemplu, la Şcoala Internaţională Grennaskolan sunt

\footnotetext{
${ }^{4}$ Muşata Bocoş, Dana Jucan, Fundamentele pedagogiei, Teoria şi metodologia curriculum-ului, Repere şi instrumente didactice pentru formarea profesorilor, Piteşti, Edit. Paralela 45, 2010, p. 111.

${ }^{5}$ Dorin Corneliu Opriş, The Religious Experience Issues of the Members of Church Choirs. A Gender Analysis, în "The International Journal of Orthodox Theology", 5:3 (2014), p. 234.
} 
menţionate exemple de opţionale: Istoria suedezilor, Ştiinţe sociale, Ştiinţe naturale şi Sport ${ }^{6}$.

O altă ţară nordică, Finlanda, are la bază studiul opţionalelor care trebuie să sprijine obiectivele educaţiei de bază, sarcina de bază în instruire este de a oferi elevilor şansa de a-şi aprofunda interesele personale de dezvoltare şi de a găsi noi domenii de interes. În această ţară opţionalele sunt cross-curriculare, iar cele mai vizate sunt limbile străine ${ }^{7}$.

În Republica Cehă, numărul orelor de opţional este decis de către directorii şcolilor şi oferă creşterea unei varietăţi a domeniilor educaţionale $^{8}$.

În Coreea de Sud sunt propuse discipline opţionale în special în relaţie cu limbile străine, tehnologia informaţiei şi educaţia ecologică ${ }^{9}$.

Cuprinzând sisteme de valori identificate şi vehiculate la nivelul societăţii, acestea oferă sistemului educativ linii directoare, îi asigură acestuia coerenţa şi dau sensuri noi acţiunii educative. Este necesar, în paralel, ca elevii să fie educaţi în vederea identificării propriilor trebuinţe educaţionale şi transformării acestora în obiective, pe baza unui schimb de informaţii în legătură cu rolurile asumate şi cu aşteptările fiecărei părţi. Educaţia de calitate înseamnă o acţiune eficientă bazată pe experienţa actorilor educaţiei, având la bază o teorie pedagogică şi psihologică bine fundamentată.

\footnotetext{
${ }^{6}$ http://www.grennaskolan.se/english/grennaskolan/education/introduktionskurs .html (accesat la data de 20.03.2016).

747673 core_curricula_basic_education_4 Finland.pdf, p. 49.

${ }^{8}$ Wolfgang Horner, Hans Dobert, Botho von Kopp, and Wolfgang Mitter, The Educational Systems of Europe, Published by Springer, Netherlands, 2007, p.176.
}

${ }^{9}$ http://www.ncee.org/programs-affiliates/center-on-international-educationbenchmarking/top-performing-countries/south-korea-overview/south-koreainstructional-systems/ (accesat la data de 20.03.2016). 


\section{Studiu experimental asupra opţionalului Elemente de practică religioas̆a}

Realizând un interviu cu mai mulţi profesori ${ }^{10}$ despre ceea ce înseamnă opţionalul şi rolul acestuia în activitatea didactică, am constatat că utilizarea acestui instrument curricular este susţinută de libertatea pe care o oferă în stabilirea parcursului prin posibilitatea de alegere a conţinuturilor învăţării în raport cu particularităţile individuale şi de vârstă ale elevilor. Cei mai mulţi profesori preferă ca opţionalul să vină în completarea curriculum-ului oficial şi să aibă un caracter practic-aplicativ.

Literatura de specialitate arată modul în care

„complexitatea fenomenului educaţional religios, nevoia de ancorare permanentă la realităţile din sfera religiosului, dar şi de adaptare la schimbările din societate, necesitatea optimizării permanente a activităţii educative pe toate componentele şi subcomponentele acesteia ridică o serie de întrebări al căror răspuns poate fi dat doar pe baza rezultatelor cercetărilor pedagogice" $"$.

De aceea am considerat oportun să propun un opţional la clasa a IV-a şi să observ impactul acestuia asupra elevilor. Opţionalul Elemente de practică religioasă a fost un opţional la nivelul disciplinei având durata de un an şcolar, cu o oră pe săptămână. Activităţile au fost diverse: lecţii, participare la slujbe la biserica din sat, excursii, vizite la mănăstiri şi lăcaşuri de cult, serbări, scenete. Prin conţinuturile vizate vine în completarea celor predate la ora de religie, iar prin activităţile desfăşurate urmăreşte consolidarea deprinderilor religioase; scopul final este susţinerea apropierii copiilor de Dumnezeu.

\footnotetext{
${ }^{10}$ Interviul s-a realizat cu 15 profesori de specialităţi diferite, din cadrul Şcolii Gimnaziale „Dosa Daniel”, Valea Izvoarelor, judeţul Mureş.

${ }^{11}$ Monica Opriş, Dorin Opriş, Cercetare şi religie, repere şi demersuri comune, Cluj-Napoca, Edit. Eikon, 2013, p.17.
} 
Pentru a-mi atinge scopul am recurs la următoarele conţinuturi: Biserica-Casa Domnului; Sfânta Liturghie-centrul cultului ortodox; Timpurile liturgice; Cântarea bisericească. Diversitatea lecţiilor, metodelor şi mijloacelor utilizate în cadrul opţionalului pun în prim plan actul învăţării şi al evaluării, declanşând, stimulând şi orientând ansamblul activităţilor şcolare ale elevului. Formele de organizare a activităţii didactice realizabile în diferite contexte conform obiectivelor elaborate la nivel general, specific şi concret vizează perfecţionarea corelaţiei profesor-elev urmărind mai ales dezvoltarea vieţii afectiv-religioase a elevilor.

\section{1. Ipoteza şi obiectivele cercetării}

Am pornit de la ipoteza: utilizarea in mod adaptat la particularităţile individuale şi de grup ale elevilor a conţinutului invățării în cadrul opționalului Elemente de practică religioasă, la clasa a IV-a, conduce la modificări în plan cognitiv, afectiv şi volitiv.

Am urmărit evidenţierea modificărilor în planul relaţiilor elev-elev şi elev-profesor, ca urmare a derulării activităţilor didactice programate în cadrul opţionalului, dar şi detalierea unor particularităţi privind rolul muzicii religioase în reconstruirea unor elemente ale modelului de grup, în cadrul clasei. Un alt aspect vizat a fost stabilirea nivelului de interes al elevilor faţă de diferite tipuri de conţinut utilizate în cadrul opţionalului. Astfel, am ajuns la identificarea rolului opţionalului Elemente de practică religioasă în susţinerea demersurilor educative de la ora de religie, la clasa inclusă in cercetare.

\section{2. Alegerea şi prezentarea particularităţilor eşantionului de subiecţi}

Opţionalul a fost aplicat la a IV-a C din cadrul Şcolii Gimnaziale Dosa Daniel Valea Izvoarelor - structura Chirileu pe parcursul anului şcolar 2014-2015, având un număr de 22 de elevi (12 băieţi şi 9 fete plus un băiat transferat în semestrul al II-lea). 


\section{$15^{\text {th }}$ International Symposium on Science, Theology and Arts}

Vârsta elevilor a fost cuprinsă între 9-10 ani. Elevii provin din mediul rural, din familii de muncitori, cu sau fără studii medii, şomeri, casnici sau liber profesionişti.

\subsection{Metode de cercetare utilizate}

Pentru a observa ce s-a întâmplat cu elevii pe parcursul cercetării am recurs la diverse metode de cercetare: observaţia directă, metoda anchetei (convorbirea şi chestionarea), metoda cercetării documentelor şcolare, metoda analizei produselor realizate de către elevi şi metoda testelor.

Metoda anchetei bazată pe chestionar a fost folosită pentru relevarea unor opinii, interese, dorinţe în legătură cu viaţa duhovnicească a elevilor. Astfel că s-au aplicat elevilor 2 chestionare identice: unul la începutul anului şcolar şi altul la finalul anului şcolar. În urma aplicării acestora s-au constatat următoarele:

- 90,47\% din elevi merg cu plăcere la biserică;

- 38,09\% participă săptămânal la slujbe, iar un procent de $\mathbf{2 8 , 5 7 \%}$ participă doar o dată sau de două ori pe an;

- 52,38\% consideră că slujba este prea lungă;

- $\mathbf{6 1 , 9 0 \%}$ s-au spovedit anul acesta, iar $\mathbf{2 3 , 8 0 \%}$ anul trecut;

- 47,61\% dintre elevi sunt atraşi la biserică de cântecele de la strană.

Metoda observaţiei este o metodă centrată pe analiza conduitei şi a fost folosită pe tot parcursul anului şcolar. Obiectul observaţiei 1-au fãcut 4 elevi aleşi în funcţie de frecvenţa participării la slujbe. Pentru a putea cuantifica datele privind evoluţia elevilor pe parcursul anului şcolar, consemnarea pe fişe de observaţie a unor aspecte din comportamentul, atitudinile şi reacţiile elevilor în cadrul vizitelor la biserica din sat, din timpul lecţiilor desfăşurate, al scenetelor de Crăciun şi Paşti, participării la slujbe, a constituit mijlocul de realizare a acestei metode. S-a constatat că elevii au avut schimbări de atitudini şi comportament în urma aplicării opţionalului.

Prin metoda cercetării documentelor şcolare s-a urmărit modul în care elevii îşi iau notiţe şi aspectul general al caietelor şi al fişelor de lucru. 
Aspecte pozitive constatate:

- majoritatea elevilor îşi iau notiţe;

- peste 50\% dintre elevii clasei au caiete îngrijite şi ordonate;

- majoritatea elevilor rezolvă cu uşurinţă în mod corect sarcinile de lucru.

Aspecte negative constatate:

- unii elevi au caiete comune pentru mai multe discipline;

- nu toţi elevii care absentează îşi completează caietele cu noţiunile predate în lipsa lor;

- unii copii fac greşeli de ortografie şi au scrisul indescifrabil.

Metoda interviului a vizat obţinerea informaţiilor necesare constatării impactului pe care 1-a avut opţionalul predat mai ales asupra unui elev nou venit şi nu numai. Din semestrul al II-lea un elev s-a transferat de la o şcoală dintr-o localitate apropiată. Din setul de întrebări la care a răspuns elevul intervievat, se poate admite faptul că opţionalul a fost o reuşită.

Metoda testelor pedagogice este o metodă de măsurare a cunoştinţelor şi a achiziţiilor şcolare, iar în cercetarea de faţă s-au analizat şi interpretat rezultatele elevilor la 3 probe de evaluare: testul iniţial (aplicat în septembrie 2014), testul formativ (de la finalul semestrului I) şi testul final (iunie 2015).

Testul iniţial a fost conceput şi administrat cu scopul diagnosticării nivelului de performanţă şi a lacunelor intervenite în pregătirea fiecărui elev în parte la disciplina religie, până la data începerii anului şcolar $2014-2015$.

\begin{tabular}{|c|c|c|c|c|c|c|c|}
\hline Nota & $\mathbf{4}$ & $\mathbf{5}$ & $\mathbf{6}$ & $\mathbf{7}$ & $\mathbf{8}$ & $\mathbf{9}$ & $\mathbf{1 0}$ \\
\hline Frecvența & 4 & 6 & 4 & 2 & 4 & 1 & 1 \\
\hline
\end{tabular}

\section{Tabel nr. 1 Tabel sintetic cu rezultatele evaluării iniţiale}

Se observă că în urma testului predictiv cunoştinţele elevilor sunt de nivelul mediu. În urma rezultatelor obţinute la testul iniţial în 
vederea însuşirii de către elevi a conceptelor referitoare la noţiunile de liturgică, s-a stabilit necesitatea aplicării unor metode variate.

Experimentul fiind longitudinal, urmăreşte rezultatele obţinute de elevii aceluiaşi eşantion, într-un timp dat, folosind metode diferite şi activitatea de muncă independentă şi diferenţiată, pentru însuşirea sau consolidarea cunoştinţelor teoretice şi practice din cadrul procesului de învăţământ.

După aplicarea testului formativ se poate observa că rezultatele celor două teste sunt asemănătoare, cu o uşoară creştere a frecvenţei notelor de 6, 9 şi 10 . Efectele benefice ale aplicării modelului s-au resimţit pe toată perioada administrării factorului experimental, la majoritatea subiecţilor. Astfel, în urma parcurgerii întregii materii planificate pentru semestrul al II-lea şi îmbinând învăţarea în clasă cu mai multe tipuri de lecţii (lecţii de recapitulare, fixare şi consolidare a cunoştinţelor, lecţii mixte, lecţii desfăşurate în biserică, etc.) s-au obţinut rezultate încurajatoare.

\begin{tabular}{|c|c|c|c|c|c|c|c|}
\hline Nota & $\mathbf{4}$ & $\mathbf{5}$ & $\mathbf{6}$ & $\mathbf{7}$ & $\mathbf{8}$ & $\mathbf{9}$ & $\mathbf{1 0}$ \\
\hline Frecvența & 1 & 4 & 5 & 2 & 2 & 3 & 2 \\
\hline
\end{tabular}

Tabel nr. 2 Tabel sintetic cu rezultatele evaluării formative

Iar pentru a observa beneficiile cognitive ale opţionalului derulat pe parcursul anului şcolar 2014-2015 în iunie 2015 s-a aplicat elevilor testul final. Se observă din nou o creştere considerabilă a notelor de trecere 5, 6 dar şi a notelor de 8, 9, 10 .

\begin{tabular}{|c|c|c|c|c|c|c|c|}
\hline Nota & $\mathbf{4}$ & $\mathbf{5}$ & $\mathbf{6}$ & $\mathbf{7}$ & $\mathbf{8}$ & $\mathbf{9}$ & $\mathbf{1 0}$ \\
\hline Frecvenţa & 1 & 5 & 5 & 5 & 1 & 2 & 3 \\
\hline
\end{tabular}

\section{Tabel nr. 3 Tabel sintetic cu rezultatele evaluării finale}

\section{Metoda analizei produselor activităţii realizate de către} elevi a vizat abilităţile şi înclinaţiile elevilor pentru realizarea de proiecte, creativitate şi imaginaţie în realizarea compunerilor. Li s-a cerut elevilor să realizeze două proiecte pe parcursul întregului an 
şcolar. Primul proiect a fost întitulat Biserica, loc de întâlnire cu Dumnezeu, în care copii au prezentat evenimentele religioase din viaţa lor începând cu sfânta taină a cununiei părinţilor şi încheind cu o zi de duminică la biserică. De asemenea, elevii au avut posibilitatea de a scrie ghicitori, poezii şi de a realiza desene sugestive temei date. Al doilea proiect a fost dedicat Sărbătorii Învierii în familia mea în care elevii au creat compuneri cu titlul Învierea în familia mea, ghicitori şi poezii. De asemenea, au fost rugaţi să realizeze un desen cu titlul Eu şi biserica. Colaborarea permanentă cu profesoara de spijin a şcolii, a facilitat interpretarea detaliată a acestor produse.

\section{4. Rezultatele cercetării}

$\mathrm{Cu}$ ajutorul metodelor folosite în cercetarea de faţă s-a reuşit implementarea opţionalului Elemente de practică religioasă la clasa a IV-a şi observarea progresului elevilor atât din punct de vedere cognitiv, cât şi din punct de vedere afectiv-volitiv.

Astfel s-au aplicat la clasă două chestionare identice: unul la început şi celălalt la sfârşitul anului şcolar. În urma aplicării chestionarului s-a constatat o îmbunătăţire a atitudinilor faţă de biserică şi practica religioasă a elevilor. Tot la începutul anului şcolar s-a aplicat testul iniţial menit să reflecte bagajul de cunoştinţe al elevilor şi lacunele acestora în ceea ce priveşte latura cognitivă a predării acestui opţional. Pe baza rezultatelor obţinute la acest test, sau implementat la clasă strategii didactice cât mai diverse şi mai atractive pentru a facilita participarea elevilor la ore, scenete şi alte activităţi. Astfel la sfârşitul primului semestru în urma aplicării testului de evaluare formativă, s-a constatat o îmbunătăţire a rezultatelor elevilor comparativ cu rezultatele obţinute la evaluarea iniţială. În semestrul al II-lea al anului şcolar 2014-2015 s-a continuat îmbinarea metodele tradiţionale de predare $\mathrm{cu}$ cele moderne, şi folosirea mijloacelor didactice atractive pentru elevi (calculatorul, videoproiectorul, casetofonul).

Tot pe parcursul acestui semestru s-au centralizat comportamentele observabile ale elevilor la diverse activităţi, s-a 
intervievat un elev nou venit, s-au completat fişele de observaţie pentru 4 elevi cu caracter diferit în ceea ce priveşte comportamentul religios, s-au analizat desene care evidenţiază relaţia dintre elevi şi biserică şi s-a realizat sceneta de Paşti.

Prin toate aceste activităţi a fost vizată latura afectiv-volitivă a elevilor, având urmări pozitive în implicarea acestora în diverse activităţi chiar şi extraşcolare. Totodată prin aceste activităţi a fost dezvoltată şi partea cognitivă, fapt care s-a obiectivat în rezultatele evaluării finale.

\begin{tabular}{|c|c|c|c|c|c|c|c|}
\hline Nota & $\mathbf{4}$ & $\mathbf{5}$ & $\mathbf{6}$ & $\mathbf{7}$ & $\mathbf{8}$ & $\mathbf{9}$ & $\mathbf{1 0}$ \\
\hline $\begin{array}{c}\text { Frecvența notelor } \\
\text { la } \\
\text { evaluarea iniţială }\end{array}$ & 4 & 6 & 4 & 2 & 4 & 1 & 1 \\
\hline $\begin{array}{c}\text { Frecvența notelor } \\
\text { la } \\
\text { evaluarea } \\
\text { formativă }\end{array}$ & 1 & 4 & 5 & 2 & 2 & 3 & 2 \\
\hline $\begin{array}{c}\text { Frecvența notelor } \\
\text { la } \\
\text { evaluarea finală }\end{array}$ & 1 & 5 & 5 & 5 & 1 & 2 & 3 \\
\hline
\end{tabular}

Tabel nr. 4 Tabel sintetic comparativ cu rezultatele evaluării iniţiale, formative şi finale
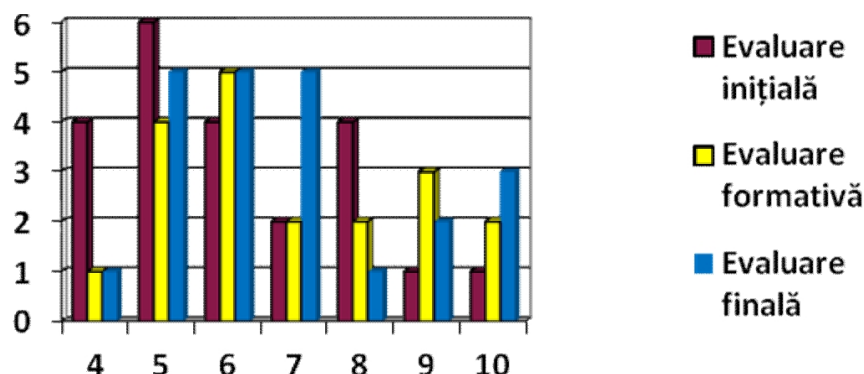

$\begin{array}{lllllll}4 & 5 & 6 & 7 & 8 & 9 & 10\end{array}$

Fig. 1 Diagramă de comparaţie a progresului instruirii la sfârşitul anului şcolar 
Prin urmare notele de 4 au scăzut la evaluarea finală cu $14 \%$ faţă de evaluarea iniţială, iar notele de 6 au crescut la evaluarea finală cu 5\% faţă de evaluarea iniţială. Dacă la evaluarea iniţială notele de 7 aveau o pondere de $9 \%$ se constată că la evaluarea finală acestea au crescut cu $16 \%$, dacă notele de 9 aveau o pondere de $5 \%$ la evaluarea iniţială se constată că şi acestea au crescut la evaluarea finală cu 4 \%. Notele de 10 aveau o pondere doar de $5 \%$ la evaluarea iniţială se constată că şi acestea au crescut la evaluarea finală cu $11 \%$. Se constată un progres la majoritatea elevilor sau cel puţin păstrarea unui interes constant faţă de aplicarea practicii religioase.

Prin urmare, predarea acestui opţional i-a ajutat pe elevi să-şi însuşească cunoştinţe teoretice şi să-şi îmbogăţească viaţa duhovnicească, dar a constituit o experienţă pozitivă şi pentru dascăl.

\section{Concluzii}

Cercetarea de faţă a pornit de la necesitatea de a ajuta elevul atât în însuşirea regulilor, tradiţiilor şi valorii evenimentelor religioase ale Bisericii Ortodoxe, cât şi în dobândirea deprinderilor, obişnuinţelor spirituale, care îl înalţă, îl fac mai bun, mai respectuos, mai responsabil. Elevii vor înţelege treptat şi în mod liber că toate acestea sunt un rezultat al dragostei lui Dumnezeu pentru oameni şi răspunsul credinciosului la chemarea divinităţii.

Numărul de ore alocat prin planul cadru disciplinei Religie este limitat la o oră pe săptămână, timp în care formarea unui sistem de noţiuni şi deprinderi este îngreunată. $\mathrm{Cu}$ scopul creşterii gradului de implicare al elevului în activitatea desfăşurată la orele de Religie s-au testat efectele pe care introducerea unui opţional desprins din cerinţele acestei discipline le-ar avea asupra randamentului şcolar al elevilor, a gradului de implicare în parcurgerea acestei discipline.

S-a observat că utilizarea frecventă a termenilor şi noţiunilor de liturgică şi în afara orelor specifice a condus la însuşirea corespunzătoare a lor, a determinat formarea unui limbaj specializat. Elevii au fost puşi în situaţia de a acţiona, a crea, de a lucra individual şi în echipă. Studiul opţionalului a depăşit de multe ori în 


\section{$15^{\text {th }}$ International Symposium on Science, Theology and Arts}

acest scop spaţiul sălii de clasă, biserica fiind mediul cel mai potrivit în care elevii au observat şi înţeles noţiunile şi au pus în practică cele învăţate.

Predarea bazată pe metode active i-a ajutat pe elevi să devină ei înşişi, urmărind schimbarea în bine a acestora şi formarea unor noi competenţe, ca urmare a interacţiunii lor cu noul conţinut. Utilizând strategii optime şi un conţinut adecvat, la sfârşitul anului şcolar elevii au fost capabili să utilizeze adecvat limbajul specific liturgic, să adopte un comportament favorabil în biserică, să argumenteze necesitatea aplicării unui anumit comportament, să realizeze un proiect tip carte. Activităţile extraşcolare, scenetele de pildă, au oferit o imagine foarte clară a comportamentelor pozitive precum: perseverenţa memorării şi intrepretării rolurilor, seriozitatea în confecţionarea sau chiar închirierea recuzitei. Prin intermediul desenelor realizate la ore s-a putut observa relaţia dintre elevbiserică, apropierea faţă de aceasta, inteligenţa, atitudinea, comportamentul şi nu în ultimul rând familiaritatea faţă de aceasta. De asemenea, elevii au avut posibilitatea de a se reprezenta pe ei înşişi în relaţie directă cu biserica; de aceea au fost realizate cu mult entuziasm şi plăcere. Pe baza observaţiei directe asupra activităţii elevilor s-a mai constatat că aceştia sunt mai interesaţi şi mai activi, cu cât lecţia are un conţinut informaţional mai apropiat de posibilitatea transpunerii şi utilizării lui în practică. Elevii preferă ca metode de lucru conversaţia, problematizarea, asaltul de idei, ciorchinele.

Pe lângă cunoştinţele asimilate la lecţii, elevii au rămas şi cu frumuseţea imaginilor care le rămân tipărite în minte datorită mijloacelor moderne folosite în cadrul orelor. Opţionalul propus a venit în sprijinul completării bagajului de cunoştinţe şi aptitudini al elevilor, aceştia familiarizându-se cu noţiunile referitoare la viaţa practică a creştinului care nu erau cuprinse în conţinutul lecţiilor de religie. Mai mult decât atât, s-au completat conţinuturile disciplinei cu diferite date, s-au făcut analogii, aprecieri, s-au rezolvat diverse situaţii problemă şi chiar studii de caz, s-au regăsit parţial în viaţa unor sfinţi, toate acestea ajutându-i să perceapă necesitatea trăirii 
vieţii duhovniceşti. Ca o rezultantă a acestui fapt $\mathrm{s}$-a conturat evidenţierea locului şi asumarea rolului pe care fiecare dintre ei îl are în vederea bunei funcţionări a vieţii creştine. Efectul acestor intervenţii s-a oglindit în rezultatele progresive obţinute la teste.

Analizând rezultatele celui de-al doilea chestionar se poate concluziona că s-a reuşit sensibilizarea elevilor şi îndrumarea lor către locaşurile de cult, conştientizarea importanţei sărbătorilor şi a participării la slujbe. Mulţi elevi au devenit mai atenţi cu colegii şi cu profesorii lor. Referitor la interesul/dezinteresul manifestat de unii elevi, s-a observat că sunt mai activi şi mai interesaţi cei care au o educaţie religioasă primită în familie, care participă la slujbele bisericii alături de părinţi, decât cei pentru care legătura cu Dumnezeu se realizează doar prin prisma orei de religie.

Cercetarea de faţă a avut o influenţă pozitivă şi asupra cadrului didactic prin formarea unei imagini de ansamblu asupra relaţiei elev-biserică-divinitate.

Interviul colectiv a oferit datele necesare realizării feedbackului acestui opţional. Majoritatea elevilor au afirmat că le-a plăcut opţionalul, excepţie făcând un singur copil. Printre lecţiile preferate de elevi se situează următoarele: Cum mă comport în biserică ?, Sărbătorile creştine in general şi Pricesnele şi colindele. Activităţile ce se doresc a fi repetate sunt scenetele, vizionarea de filmuleţe şi munca pe grupe, ceea ce denotă faptul că opţionalul se doreşte a fi continuat, poate cu o altă structură.

Ca parte implicată în această cercetare, în vederea utilizării la maxim a valenţelor oferite de acest opţional se întrevede oportunitatea parcurgerii acestuia pe parcursul întregului gimnaziu. 


\section{Bibliografie}

1. Bocoş, Muşata, Jucan, Dana, Fundamentele pedagogiei, Teoria şi metodologia curriculum-ului, Repere şi instrumente didactice pentru formarea profesorilor, Piteşti, Edit. Paralela 45, 2010.

2. Cucoş, Contantin (coord.), Psihopedagogie pentru examenele de definitivare şi grade didactice, Iaşi, Edit. Polirom, 1998.

3. Holbea, Gheorghe, Opriş, Dorin, Opriş, Monica, and Jambore, George, Apostolat educaţional, Ora de religie - cunoaştere şi devenire spirituală, Bucureşti, Edit. Basilica a Patriarhiei Române, 2010.

4. Horner, Wolfgang, Dobert, Hans, Botho von Kopp, and Mitter, Wolfgang, The Educational Systems of Europe, Published by Springer, Netherlands, 2007.

5. Opriş, Dorin Corneliu, The Religious Experience Issues of the Members of Church Choirs. A Gender Analysis, în The International Journal of Orthodox Theology, 5:3 (2014).

6. Opriş, Monica, Opriş, Dorin, Cercetare şi religie, repere şi demersuri comune, Cluj-Napoca, Edit. Eikon, 2013.

7. Sfântul Grigorie de Nyssa, Despre rânduiala cea după Dumnezeu (a vieţii) şi despre nevoinţa cea adevărată, în Scrieri, partea întâi, trad. de D. Stăniloae şi I. Buga, în col. Părinţi şi Scriitori Bisericeşti, vol. 29, Bucureşti, Edit. Institutului Biblic şi de Misiune al Bisericii Ortodoxe Române, 1982.

8. 47673 core_curricula_basic_education_4 Finland.pdf.

9. http://Www.grennaskolan.se/english/grennaskolan/education/introdukti onskurs.html (accesat la data de 20.03.2016)

10. http://www.ncee.org/programs-affiliates/center-on-internationaleducation-benchmarking/top-performing-countries/south-koreaoverview/south-korea-instructional-systems/ (accesat la data de 20.03.2016) 